\title{
Multilocus Genotyping and Intergenic Spacer Single Nucleotide Polymorphisms of Amylostereum areolatum (Russulales: Amylostereacea) Symbionts of Native and Non-Native Sirex Species
}

\author{
Ming Wang ${ }^{1,2}\left(\mathbb{D}\right.$, Ningning Fu ${ }^{1,2}\left(\mathbb{D}\right.$, Chenglong Gao ${ }^{1,2}$, Lixia Wang ${ }^{1,2}$, Lili Ren ${ }^{1,2, *(D)}$ and Youqing Luo ${ }^{1,2, *(\mathbb{D})}$ \\ 1 Beijing Key Laboratory for Forest Pest Control, Beijing Forestry University, Beijing 100083, China; \\ 13020028768@163.com (M.W.); funingning2012@sina.com (N.F.); gaocl890907@163.com (C.G.); \\ wlxynl@163.com (L.W.) \\ 2 Sino-French Joint Laboratory for Invasive Forest Pests in Eurasia, INRAE-Beijing Forestry University, \\ Beijing 100083, China \\ * Correspondence: lily_ren@bjfu.edu.cn (L.R.); youqingluo@126.com (Y.L.)
}

check for updates

Citation: Wang, M.; Fu, N.; Gao, C.; Wang, L.; Ren, L.; Luo, Y. Multilocus Genotyping and Intergenic Spacer Single Nucleotide Polymorphisms of Amylostereum areolatum (Russulales: Amylostereacea) Symbionts of Native and Non-Native Sirex Species. J. Fungi 2021, 7, 1065. https://doi.org/ 10.3390/jof7121065

Academic Editor: Ivan M. Dubovskiy

Received: 18 November 2021

Accepted: 9 December 2021

Published: 11 December 2021

Publisher's Note: MDPI stays neutral with regard to jurisdictional claims in published maps and institutional affiliations.

Copyright: (c) 2021 by the authors. Licensee MDPI, Basel, Switzerland. This article is an open access article distributed under the terms and conditions of the Creative Commons Attribution (CC BY) license (https:// creativecommons.org/licenses/by/ $4.0 /)$.

\begin{abstract}
Sirex noctilio along with its mutualistic fungal symbiont, Amylostereum areolatum (a white rot fungus), is an invasive pest that causes excessive damage to Pinus plantations in Northeast China. In 2015, S. noctilio were found to attack Pinus sylvestris var. mongolica, and often share larval habitat with the native woodwasp, S. nitobei. The objective of this study was to determine the possible origin(s) of the introduced pest complex in China and analyse the genetic diversity between A. areolatum isolated from invasive $S$. noctilio, native $S$. nitobei and other woodwasps collected from Europe (native range) and other countries. Phylogenetic analyses were performed using the intergenic spacer (IGS) dataset and the combined 4-locus dataset (the internal transcribed spacer region (ITS), translation elongation factor alpha 1 (tef1), DNA-directed ribosomal polymerase II (RPB2), and mitochondrial small subunit (mtSSU)) of three Amylostereum taxa. The multilocus genotyping of nuclear ribosomal regions and protein coding genes revealed at least three distinct multilocus genotypes (MLGs) of the fungus associated with invasive $S$. noctilio populations in Northeast China, which may have come from North America or Europe. The IGS region of A. areolatum carried by S. noctilio from China was designated type B1D2. Our results showed a lack of fidelity (the paradigm of obligate fidelity to a single fungus per wasp species) between woodwasp hosts and A. areolatum. We found that the native $S$. nitobei predominantly carried A. areolatum IGS-D2, but a low percentage of females instead carried A. areolatum IGS-B1D2 (MLG A13), which was presumably due to horizontal transmission from $S$. noctilio, during the sequential use of the same wood for larval development. The precise identification of the $A$. areolatum genotypes provides valuable insight into co-evolution between Siricidae and their symbionts, as well as understanding of the geographical origin and history of both Sirex species and their associated fungi.
\end{abstract}

Keywords: Sirex-Amylostereum; phylogeny; multilocus genotypes; co-occurrence; genetic diversity; population structure

\section{Introduction}

The genus Amylostereum comprises four species, namely the type species A. chailletii (Pers.:Fr.) Boid. (=Stereum chailletii), A. areolatum (Fr.) Boid. (=S. areolatum), A. laevigatum (Fr.) Boid (=Peniophora laevigata), and A. ferreum (Berk. and Curt.) Boid. and Lanq. (=S. ferreum). Of these species, the wood-rotting basidiomycetes $A$. areolatum and $A$. chailletii are well known for their mutualistic association with siricid woodwasps [1-5]. During oviposition, woodwasps inoculate a symbiotic fungus, Amylostereum, in the host tree, which exhibits the ability to cause serious damage and mortality of various conifer species, and is also the primary food source for developing wasp larvae [6-12]. However, Sirex noctilio 
F. and its symbiotic fungus, $A$. areolatum, are the only members of Siricidae that regularly invade living trees $[6,13]$. In Northeast China, S. noctilio has successfully colonized Pinus sylvestris var. mongolica as the main host in the field [14].

The S.noctilio-A. areolatum complex is native to Europe and North Africa, where $S$. noctilio is considered to be a secondary pest of little economic importance $[10,13,15]$. In these regions, trees are rarely killed, and they may support a colony of woodwasps for more than one season $[13,16]$. By contrast, in the southern hemisphere and in Northeast China, the species has been causing extensive damage to pine plantations [11-13,17,18]. Notably, existing S. noctilio Integrated Pest Management (IPM) programs involve the use of biological control agents in combination with preventative silvicultural practices, which have exhibited obvious control effects in countries with a high degree of pest invasion $[19,20]$.

A. areolatum, a saprophyte remaining in the tree after emergence of the wasp, can fruit and theoretically spread by means of basidiospores. The close association of $A$. areolatum with its woodwasp symbiont may be the reason that it rarely reproduces sexually in some areas of its native range, and is not yet known to fruit in its introduced region [21]. Several studies based on vegetative (or somatic) incompatibility have revealed that the isolates from South Africa and South America belong to the same vegetative compatibility group (VCG), and isolates from Lithuania, Sweden, Denmark and Great Britain share the same VCG [22-24]. The clonal lineages (groups of isolates with identical DNA fingerprinting profiles) of A. areolatum, primarily spreading vegetatively over wide geographic areas, have indicated the importance of insect vectors in the spread of fungi and the formation of dispersive clones or VCGs [22,24-26].

The introduction of S. noctilio into Northeast China and the confinement of this species to a rather small area in the country provides us with an opportunity to investigate the population of its fungal symbiont in detail. Despite much interest in these fungus-woodwasp symbioses, investigations on the population structure and phylogenetic relationships of the fungal symbiont of Sirex have been scarce in China. Wang et al. (2018) have revealed the significant, phylogenetic congruence between Diaphorina citri (Hemiptera: Liviidae) and Candidatus Carsonella ruddii, suggesting that the P-endosymbiont may facilitate investigations into the genealogy and migration history of the host [27]. Tracing the sources of the $S$. noctilio- $A$. areolatum complex could help determine the routes of its spread, and prevent future introductions. To study the introduced S. noctilio and its associated $A$. areolatum genotypes in China, we determined the genetic diversity of the Amylostereum spp. associated with S. noctilio and other woodwasps from Europe, and compared the observed genotypes with those of $S$. noctilio, collected from Northeast China.

The present study aims to investigate the phylogenetic relationship between Sirex and its fungal symbiont in different collection locations. In Northeast China, S. nitobei is the only native woodwasp exhibiting partly overlapping geographic distributions and host ranges with the introduced S. noctilio $[14,28]$, which allows the possibility of host trees with mixed Sirex infestations. In regions where both woodwasps occur, native woodwasps emerge in the fall and attack P. sylvestris var. mongolica, whereas S. noctilio emerge earlier [14]. In some cases, the two species will overlap in the temporal niche, or in the development within host trees [14]. S. nitobei have been reported to carry A. areolatum or A. chailletii [29]. Previous studies have shown that the utility of IGS regions and ITS-tef1-RPB2-mtSSU genes for genotyping A. areolatum associated with Sirex woodwasps [30]. To investigate these sequences of the Sirex-Amylostereum associations after the establishment of S. noctilio, we compared the symbiotic fungi of the invasive woodwasp $S$. noctilio with the native $S$. nitobei in sympatric (in Jinbaotun (JBT) and Yushu (YS)) and independent (in Dumeng (DM), Hegang (HG) and Linyi (LY)) distributions in China. Furthermore, these sequences allow comparison of our samples with those collected from pine trees in other continents attacked by S. noctilio. Here, we investigated the geographical origin of A. areolatum clonal lineages in the areas of Northeast China recently colonized by the $S$. noctilio- $A$. areolatum complex. 
We believe that such studies would help determine the extent of the level of specificity between the symbiont and the host.

\section{Materials and Methods}

\subsection{Sample Collection and Symbiont Isolation}

Amylostereum samples were collected from Sirex females between 2017 and 2020 from five sites, namely, Jinbaotun (JBT), Yushu (YS), Linyi (LY), Dumeng (DM), and Hegang (HG) (Figure 1a). The sampling sites also included the sites of co-occurrence (JBT and YS) of S. noctilio and S. nitobei in Northeast China. Data for 71 Sirex females (female wasps carry the fungus in internal mycangia) were sources for the Amylostereum species and genotypes were used in the present study.

Living Sirex samples were collected using two methods: (1) mature P. sylvestris var. mongolica, P. tabuliformis, and P. thunbergii with signs of infestation (e.g., resin beads in Figure 1b) were cut down in spring or early summer; portions of the trees were placed in individual mesh-bags under ambient conditions. Logs were cut into $70-\mathrm{cm}$ long bolts, and the ends were waxed to prevent contamination by other wood-rot fungi, and to conserve moisture. The S. noctilio and S. nitobei that emerged from the bolts were collected daily. For method (2), samples were collected weekly from lure-based black panel traps.

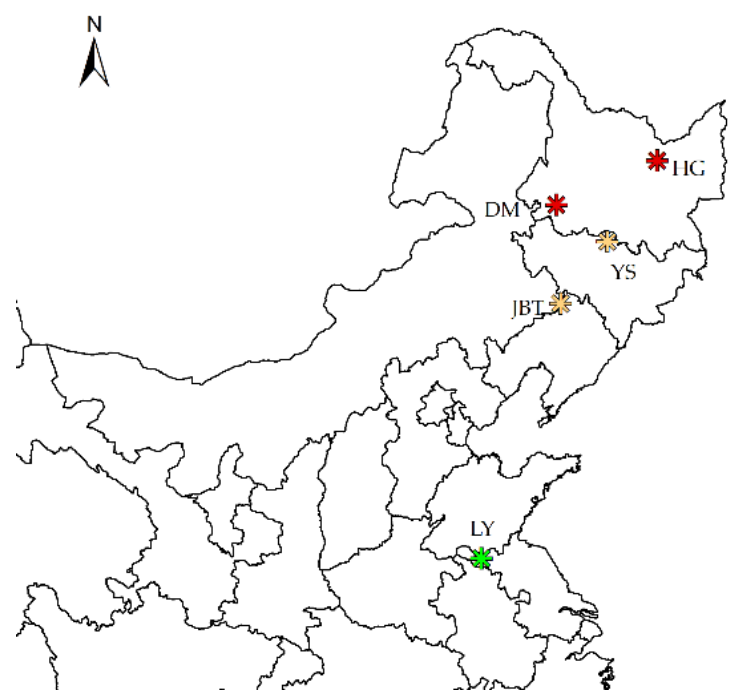

(a)

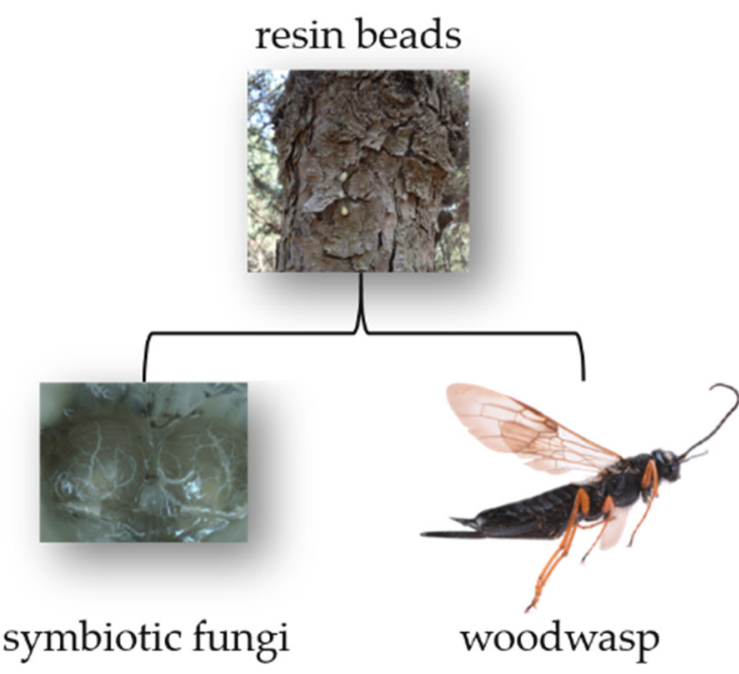

(b)

Figure 1. (a) Map of China highlighting the sampling areas (Jinbaotun (JBT), Yushu (YS), Linyi (LY), Dumeng (DM), and Hegang (HG)) in the current study; different colors represent different Sirex species present in China; red represents $S$. noctilio, green represents $S$. nitobei, and yellow represents co-occurring S. noctilio and S. nitobei. (b) Signs of infestation (resin beads) of woodwasp in the host tree and symbiotic fungi.

S. noctilio causes damage to $P$. sylvestris var. mongolica and sometimes co-infests trees with $S$. nitobei, although emergence of the relatively short-lived adult females of these two species is often separated by at least a month in Northeast China [14]. Sirex species were identified using the morphological method (the color of male abdomen and female legs) described by Schiff et al. [31]. Fungal symbiont samples could be collected only from adult female Sirex, and mycangia were removed using tweezers; the spore masses were transferred aseptically to Petri dishes with potato dextrose agar (PDA), following the method reported by Thomsen [23]. To establish fungal cultures, the contents of mycangium were transferred to a Petri dish containing PDA supplemented with antibiotics ( $300 \mathrm{mg} / \mathrm{L}$ streptomycin sulfate), whereas subsequent cultures were performed on PDA without antibiotics. Cultures were incubated in the dark at $25^{\circ} \mathrm{C} \pm 1{ }^{\circ} \mathrm{C}$ for two weeks. 


\subsection{Colony Polymerase Chain Reaction (PCR) and Sequencing}

Fifty microliter of lysis buffer (the Lysis Buffer for Microorganism to Direct PCR, Takara) was added to each $1.5-\mathrm{mL}$ microtube. Single colonies were picked using sterile pipette tips, stirred in a microtube for about five seconds and then removed. Pipette tips were not kept in the microtube for too long to avoid effects on the lysate volume and PCR amplification. After thermal denaturation at $80^{\circ} \mathrm{C}$ for $15 \mathrm{~min}$ (ThermoUnit, CHB-100, Shanghai, China), the supernatant was centrifuged (Thermo Fresco21, 75002425, Shanghai, China) at a low speed ( $3000 \mathrm{r} / 3 \mathrm{~min})$, and $1-5 \mu \mathrm{L}$ of the supernatant was taken as the template for PCR. The PCR reaction mix (T100 Thermal Cycler, Beijing, China) $(25 \mu \mathrm{L})$ is presented in Table 1, and primer sequences are presented in Table 2. Extracted DNA was stored at $4{ }^{\circ} \mathrm{C}$ until use.

Table 1. Polymerase Chain Reaction (PCR) amplification system.

\begin{tabular}{cc}
\hline Composition & Dosage $(\mu \mathrm{L})$ \\
\hline The supernatant & 1 \\
Premix Taq (Ex Taq Version 2.0$) 1.25 \mathrm{U} / 25 \mu \mathrm{L}$ & 12.5 \\
Primer (F) $10 \mathrm{pmol} / \mu \mathrm{L}$ & 1 \\
Primer (R) $10 \mathrm{pmol} / \mu \mathrm{L}$ & 1 \\
Sterile distilled water & 9.5 \\
\hline
\end{tabular}

Table 2. Primer pairs used in this study for colony PCR tests (written $5^{\prime}-3^{\prime}$ ).

\begin{tabular}{|c|c|c|c|}
\hline Target Gene & Primer Sequence $\left(5^{\prime}-3^{\prime}\right)$ & Reference & PCR Amplification Conditions \\
\hline ITS & & \multirow{3}{*}{ Gardes and Bruns (1993) [32] } & \multirow{2}{*}{$\begin{array}{l}95^{\circ} \mathrm{C} 4 \mathrm{~min} ; 95^{\circ} \mathrm{C} 1 \mathrm{~min} ; 55^{\circ} \mathrm{C} 1 \mathrm{~min} ; \\
72^{\circ} \mathrm{C} 1 \mathrm{~min} ; 72^{\circ} \mathrm{C} 10 \mathrm{~min} ; 35 \text { cycles }\end{array}$} \\
\hline $\begin{array}{l}\text { ITS1-F } \\
\text { ITS4-B }\end{array}$ & $\begin{array}{c}\text { 5'-CTTGGTCATTTAGAGGAAGTAA } \\
\text { 5'-CAGGAGACTTGTACACGGTCCAG }\end{array}$ & & \\
\hline tef1 & & & \multirow{2}{*}{$\begin{array}{c}95^{\circ} \mathrm{C} 4 \mathrm{~min} ; 95^{\circ} \mathrm{C} 1 \mathrm{~min} ; 55^{\circ} \mathrm{C} 1 \mathrm{~min} ; \\
72^{\circ} \mathrm{C} 1 \mathrm{~min} ; 72{ }^{\circ} \mathrm{C} 10 \mathrm{~min} ; 35 \text { cycles }\end{array}$} \\
\hline $\begin{array}{l}\text { tef1F } \\
\text { tef1R }\end{array}$ & $\begin{array}{c}\text { 5'-TACAAGTGCGGTGGTATTGACA } \\
\text { 5'-ACGGACTTGACTTCAGTGGT }\end{array}$ & Morehouse et al. (2003) [33] & \\
\hline$R P B 2$ & & \multirow{3}{*}{ Liu et al. (1999) [34] } & \multirow{2}{*}{$\begin{array}{l}95^{\circ} \mathrm{C} 4 \mathrm{~min} ; 95^{\circ} \mathrm{C} 1 \mathrm{~min} ; 50{ }^{\circ} \mathrm{C} 2 \text { min; } \\
72{ }^{\circ} \mathrm{C} 2 \mathrm{~min} ; 72^{\circ} \mathrm{C} 10 \mathrm{~min} ; 35 \text { cycles }\end{array}$} \\
\hline $\begin{array}{l}\text { RPB2-6F } \\
\text { fRPB2-7.c R }\end{array}$ & $\begin{array}{l}\text { 5'-TGGGGTATGGTCTGTCCTGC } \\
\text { 5'-TGGGGTATGGTCTGTCCTGC }\end{array}$ & & \\
\hline mtSSU & & & $95^{\circ} \mathrm{C} 4 \mathrm{~min} ; 95^{\circ} \mathrm{C} 1 \mathrm{~min} ; 55^{\circ} \mathrm{C} 1 \mathrm{~min}$ \\
\hline $\begin{array}{l}\text { MS1 } \\
\text { MS2 }\end{array}$ & $\begin{array}{c}\text { 5'-CAGCAGTCAAGAATATTAGTCAATG } \\
\text { 5'-GCGGATTATCGAATTAAATAAC }\end{array}$ & White et al. (1990) [35] & $72{ }^{\circ} \mathrm{C} 1 \mathrm{~min} ; 72^{\circ} \mathrm{C} 10 \mathrm{~min} ; 35$ cycles \\
\hline
\end{tabular}

\subsection{Multilocus Genotyping}

Electrophoresis was performed to examine the amplified products (Figure 2). The PCR amplicons were sent to Beijing Ruibo Biotech Co., Ltd. (Beijing, China) and sequenced using the ABI Prism ${ }^{\mathrm{TM}} 3730 \times 1$ automated DNA sequencer (Applied Biosystems USA, Foster City, California). Although the internal transcribed spacer region (ITS), translation elongation factor alpha 1 (tef1), DNA-directed ribosomal polymerase II (RPB2), and mitochondrial small subunit (mtSSU) data were obtained for all species, the four loci could not always be amplified for the same isolates. DNA sequences of the amplicons generated by forward and reverse primers were used to obtain consensus sequences by using SeqMan version 7.1.0 in DNAStar Lasergene Core Suite software (DNAStar Inc., Madison, WI, USA). Sequences were aligned using ClustalW [36] with default parameters and manually adjusted using a BioEdit Sequence Alignment Editor [37]. BLAST searches were performed in GenBank to identify related sequences. The degree of mutational saturation was evaluated using the substitution saturation index $I_{s S}$ in DAMBE version 6 [38-40]. The estimates of $I_{s s}$ were lower than the critical value $I_{s s . c}$ for all datasets $(p<0.05)$. All unique sequence data were submitted to GenBank (ITS: OL307781, OL307782; tef1: OL410536, OL410537; RPB2: OL410538-OL410540; mtSSU: OL323050, OL323051). 


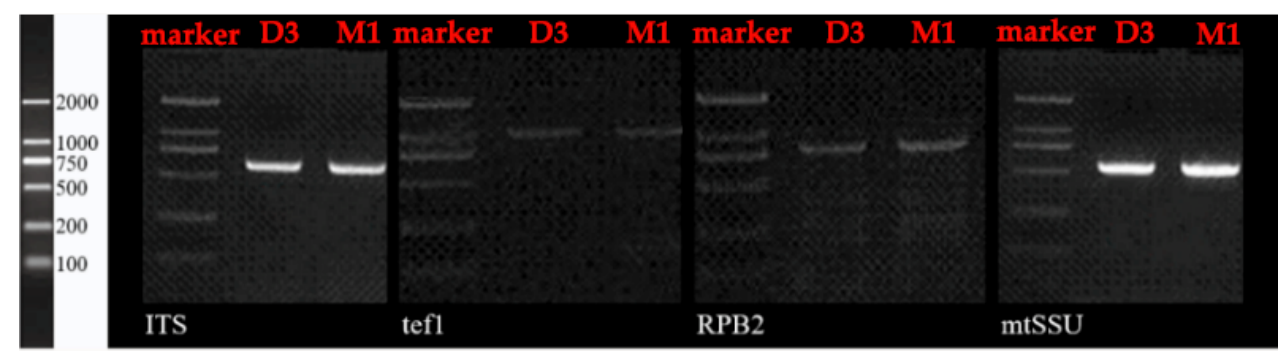

Figure 2. Visualization of the amplification of the four genes (the internal transcribed spacer region (ITS), translation elongation factor alpha 1 (tef1), DNA-directed ribosomal polymerase II (RPB2), and mitochondrial small subunit (mtSSU)) of Amylostereum isolates from Sirex, on a 1.5\% agarose gel stained with ethidium bromide.

\subsection{Fragment Analysis of Intergenic Spacer (IGS) Types}

The nuc-IGS-rDNA region between the nuclear large subunit (LSU) and the 5 S gene of ribosomal RNA (rRNA) operon was amplified using PCR primers, specific for the basidiomycetes P-1 [41] and 5S-2B [42]. All the isolates identified (by looking for oidia in culture $[43,44])$ as $A$. areolatum were verified through direct sequencing with Applied Biosystems 3730×1 DNA Analyzer (Foster City, CA, USA) at Beijing Ruibo Biotech Co., Ltd., and most isolates identified as $A$. chailletii were also verified through sequencing. The nucIGS-rDNA region may be present in $A$. areolatum as multiple copies. The primer IGS-intF (5'- GTTTCTTAGGGCTGTTCCAGACTTGTG-3') included a 7-bp "pigtail" (GTTTCTT) in the $5^{\prime}$ end. The primer 5S-2B was labeled with a FAM fluorescent marker [45]. PCR for fragment analysis was run under the following conditions: one cycle at $94{ }^{\circ} \mathrm{C}$ for $4 \mathrm{~min}$; 35 cycles of $94^{\circ} \mathrm{C}$ for $50 \mathrm{~s}, 55^{\circ} \mathrm{C}$ for $45 \mathrm{~s}$, and $72{ }^{\circ} \mathrm{C}$ for $45 \mathrm{~s}$; a final extension at $72{ }^{\circ} \mathrm{C}$ for $10 \mathrm{~min}$. The PCR temperature was maintained at $4{ }^{\circ} \mathrm{C}$ until gel visualization. Samples were mixed with formamide and LIZ500 size standard and then electrophoresed with the Applied Biosystems 3730 × 1 DNA Analyzer (Foster City, CA, USA) at Beijing Ruibo Biotech Co., Ltd.; fragment sizes were determined using GeneMarke version 2.2.0 (SoftGenetics LLC) (Figure S1).

In case of heterozygosity (at least one heterozygous site) or length heterogeneity, cloning was performed. To interpret the double product amplified for some isolates of $A$. areolatum and to obtain sequence for the whole amplified fragment, secondary PCR products were cloned for sequencing. PCR fragments were purified using the pCloneEZNRS-Omni AMP/HC Cloning Kit. Then, it was ligated to the TOPO-cloning vector and inserted into chemically competent cells of Escherichia coli. Positive colonies containing the insert were screened through PCR by using the TOPO-F and TOPO-R primers. Cloned products were precipitated and purified using the aforementioned method and sequenced using the primers TOPO-F (5'-GAGCCAGTGAGTTGATTGTG- ${ }^{\prime}$ ) and TOPO-R (5'-CAGGAAACAGCTATGACC-3').

\subsection{Data Analysis}

Heterozygous positions were coded using degenerate bases, according to the IUPACIUB nomenclature. For the phylogenetic analysis, the five newly generated sequences were combined with 17 publicly available sequences (Table 3). A. chailletii and A. laevigatum were selected as outgroups. Bayesian inference (BI) in combination with MrBayes helped in partitioning the combined datasets and concomitantly applying an independent model of evolution to each partition, because unlinked genes often have different evolutionary constraints. The combined dataset was divided into four unlinked partitions (ITS, tef1, RBB2, and mtSSU). BI analysis was performed under the Kimura 2-parameter model (Kimura, 1981) plus invariant sites (K2P + I) [46]: ITS + RPB2; Kimura-2-parameter (K2P): tef1; and the likelihood model Felsenstein 1981 plus fixed (empirical) and invariant sites (Felsenstein 1981) (F81 + F + I) [47]: mtSSU nucleotide substitution models, which were determined through ModelFinder by using the Bayesian information criterion (BIC) 
implemented in PhyloSuite 1.21 [48]. Stationarity (chain convergence) was accessed by examining the average standard deviations of split frequencies (0.002246). Maximum likelihood (ML) phylogenetic trees were constructed using IQ-TREE [49], implemented in PhyloSuite 1.21, with 10,000 replicates of ultrafast [50] bootstrap (UFBoot) and 1000 replicates of the Shimodaira-Hasegawa-like approximate-likelihood ratio test (SH-aLRT) [51]. Nodes receiving ML bootstrap values of $\geq 70 \%$ and Bayesian posterior probabilities more than 0.95 were considered significantly supported. As asexual reproduction is the predominant form of reproduction in A. areolatum, genetic analyses were conducted with a clone-corrected dataset. The relatedness of haplotype sequences to A. areolatum strains and their specificity to native or non-native Sirex species (Table S1) were analyzed through hierarchical clustering analysis (Ward method) in SAS-JMP pro version 16.0.0 software (SAS Institute Inc., Cary, NC, USA); each haplotype was scored as present (1) or absent (0). The haplotype of global A. areolatum (IGS region) distributions was mapped using POPART [52].

Table 3. Multilocus genotypes based on ITS, mtSSU, RPB2, and tef1 sequence data of Amylostereum areolatum from Sirex spp. and Urocerus spp. from various countries and sites.

\begin{tabular}{|c|c|c|c|c|c|c|}
\hline $\mathrm{MLG}^{1}$ & Isolate Code & $\begin{array}{l}\text { ITS-tef1- } \\
\text { RPB2-mtSSU } \\
\text { Types }\end{array}$ & Woodwasp/Tree Host & Collection Site & $\begin{array}{c}\text { No. } \\
\text { Samples }\end{array}$ & IGS \\
\hline \multicolumn{7}{|l|}{ A. areolatum } \\
\hline A1 & RMK11-001 & A-A-A-A & $\begin{array}{l}\text { S. juvencus, } S . \text { noctilio, } U \text {. } \\
\text { albicornis, } U \text {. gigas }\end{array}$ & $\begin{array}{l}\text { Denmark, Hungary, } \\
\text { and Spain }\end{array}$ & 16 & BC \\
\hline $\mathrm{A} 2$ & RMK11-011 & B-A-A-B & S. juvencus & Hungary & 1 & $\mathrm{BD}$ \\
\hline A3 & RMK11-022 & B-A-B-B & S. noctilio & Hungary & 1 & $\mathrm{BD}$ \\
\hline A4 & B1395 & C-A-B-B & S. nitobei & Japan & 2 & $\mathrm{D} 2$ \\
\hline A5 & GR94 & B-A-C-B & S. juvencus, S. noctilio & $\begin{array}{c}\text { Australia, Denmark, } \\
\text { Hungary, Spain, and } \\
\text { US }\end{array}$ & 14 & $\mathrm{BD}$ \\
\hline A6 & B1352 & D-A-C-B & tree source (Picea abies) & Germany & 1 & $\mathrm{D}$ \\
\hline A7 & B1385 & D-A-C-D & S. juvencus & Germany & 1 & $\mathrm{BD}$ \\
\hline A8 & AH1-17 & B-A-C-E & S. noctilio & US & 1 & $\mathrm{D}$ \\
\hline A9 & ScyME9/10 & E-B-C-C & S. nitidus & US & 1 & $\mathrm{BE}$ \\
\hline A10 & Ecogrow & F-C-D-B & Ecogrow nematode culture & Australia & 1 & $\mathrm{BD}$ \\
\hline A11 & DAOM:239281 & D-C-D-B & S. noctilio & $\begin{array}{l}\text { Canada, South Africa, } \\
\text { Chile }\end{array}$ & 8 & $\mathrm{BD}$ \\
\hline A12 & DAOM:Francke & D-C-D-D & & Germany & 1 & $\mathrm{BD}$ \\
\hline A13 & D18 & D-D-D-E & S. noctilio, S. nitobei & DM, JBT (this study) & 4 & $\mathrm{BD}$ \\
\hline A14 & D3 & D-D-E-E & S. noctilio & DM (this study) & 1 & $\mathrm{BD}$ \\
\hline A15 & D10 & D-E-D-E & S. noctilio & $\begin{array}{l}\mathrm{DM}, \mathrm{YS}, \mathrm{HG} \text {, and JBT } \\
\text { (this study) }\end{array}$ & 11 & $\mathrm{BD}$ \\
\hline A16 & M1 & G-E-B-B & S. nitobei & $\begin{array}{l}\text { JBT, LY, YS (this } \\
\text { study) }\end{array}$ & 9 & $\mathrm{D}$ \\
\hline A17 & L29 & G-D-B-B & S. nitobei & LY (this study) & 1 & $\mathrm{D}$ \\
\hline A. chailletii & & & U. gigas & $\begin{array}{c}\text { Australia, Denmark, } \\
\text { Hungary, Spain, and } \\
\text { US }\end{array}$ & 1 & \\
\hline A. laevigatum & & - & U. antennatus & Japan & 1 & \\
\hline
\end{tabular}

${ }^{1}$ Each letter represents a unique sequence for each locus, and sequence data for representative strains with different types were deposited to GenBank.

\section{Results}

\subsection{Phylogenetic Relationship in Amylostereum}

The final multilocus dataset utilized for ML and BI analyses consisted of 2116 characters (ITS: 574 characters; tef1: 345 characters; RPB2: 684 characters; mtSSU: 513 characters). Of all, 1935 characters were constant, 51 characters were variable and parsimony- 
uninformative, and 130 characters were parsimony-informative. The topology of the ML tree was mostly congruent with that of the BI tree, and the tree derived by ML was shown in Figure 3. In the A. areolatum clade, a subclade of multilocus genotypes (MLGs), A13, $\mathrm{A} 14$, and $\mathrm{A} 15$, associated with the non-native $S$. noctilio-A. areolatum from China was well supported. For IGS-D (a subclade consisting of MLGs), A4, A16, and A17 from Japan and China were the native isolates. Three strains of A. areolatum collected from S. noctilio in China had identical $\mathrm{mtSSU}$ and ITS loci (Table 3 ).

The parts of $A$. areolatum samples from the mycangia of $S$. noctilio that provided insufficient amounts of DNA for sequencing all four loci were excluded from the analysis. A total of 5 MLGs (MLGs A13-17, unique sequence) were observed in all 26 A. areolatum isolates from China (Table 3), which suggested the occurrence of at least five clonal lineages of $A$. areolatum in Northeast China. These MLGs did not match perfectly with those observed in other continents.

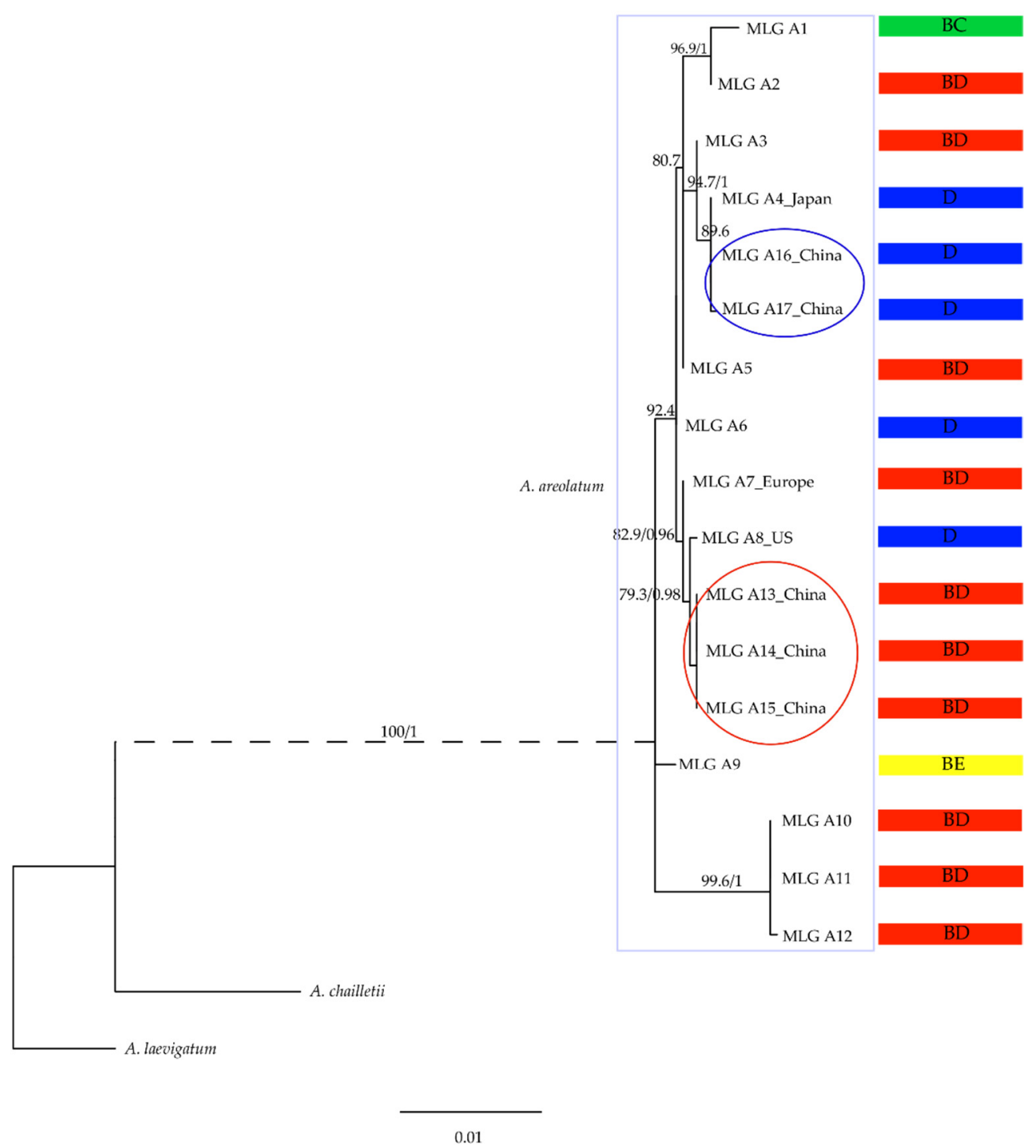

Figure 3. Phylogenetic relationships of Amylostereum spp. Majority-rule consensus tree based on the concatenated ITS, tef1, RPB2, and mtSSU genes inferred from maximum likelihood (ML) and Bayesian inference (BI) analyses. ML bootstrap values $(\geq 70 \%)$ and Bayesian posterior probabilities $(>0.95)$ are shown at the nodes. The IGS types are indicated on the right (BC, BD, D, BE). The Chinese strains are circled in red and blue. Clonal lineages with missing data for the tef1 locus were excluded from the analysis. 
Based on the sequences of ITS, mtSSU, RPB2, and tef1, the A. areolatum samples were grouped into 17 MLGs (Table 3, Figure 3). Ten of these MLGs had only one sample, whereas the remaining MLGs consisted of 2-16 samples. A1, the most widespread MLG, was observed in the S. juvencus, S. noctilio, Urocerus albicornis, and $U$. gigas samples collected from Denmark, Hungary, or Spain. The other two widespread MLGs, A5 and A15, were also detected; A5 was observed in the S. juvencus and S. noctilio samples collected from five countries, including Europe, the United States, and Australia, whereas A15 was detected in the $S$. noctilio sample only collected from China, which is a unique and dominant haplotype not found elsewhere in the rest of the world. Comparison between DNA sequences of these MLGs, and those of the samples from pine trees invaded by S. noctilio in other countries, revealed that the MLGs A13, A14 and A15 (China) were highly similar to the MLG A8 reported by Castrillo et al. (2015) in the US and the MLG A7 reported in European samples. The two strains of A. areolatum (MLGs A16 and A17) collected from S. nitobei in China revealed identical $R P B 2$ and $\mathrm{mtSSU}$ loci, and alignments showed the presence of these gene haplotypes in the Japanese samples (MLG A4) (Table 3, Figure 3).

\subsection{Haplotype Relationships Based on IGS Sequences and Fragment Analysis Data}

Two different sequences (hereafter referred to as sequence $B$ and D) for the nuc-IGSrDNA region were observed in the $A$. areolatum isolates from China. The heterogeneity in the IGS region sequences of the $A$. areolatum isolates was not observed in those of the $A$. chailletii isolates. The IGS region of $A$. areolatum sequences was obtained from 18 strains, with each strain carrying a single haplotype. According to a panel of rDNA intergenic spacer-single nucleotide polymorphisms (haplotype-specific markers) focused on the nucleotide position in the range from 206 to 276, those were designated as type D2 (Supplementary Figure S2) [53]. Fragment analysis of these strains also revealed only one peak of approximately $470 \mathrm{bp}$. The remaining 28 of the A. areolatum strains had heterogenic sequences, and their combination haplotypes were determined to be type B1D2 (two peaks of approximately $491 \mathrm{bp}$ and $470 \mathrm{bp}$ ). The IGS type was determined based on published sequences in the GenBank database and through fragment analysis of strains, with either one or a combination of two haplotypes in other countries (isolates from Nielsen et al., 2009, Wooding et al., 2013, Olatinwo et al., 2013, Rabiu et al., 2013 [53-56]).

Cluster analysis of the relatedness of haplotype sequences for A. areolatum strains and their specificity to native or non-native Sirex species (Figure 4, Supplementary Table S1) showed that the haplotype D2 was associated with the native S. nitobei isolates (M1 and L29) in China. IGS-BE and E were found only in A. areolatum from S. nigricornis (native to North America). Other haplotypes were found in A. areolatum, associated with S. noctilio. The haplotype D2 was consistently associated with the haplotype B1 found in A. areolatum from non-native S. noctilio (except for the isolate GR94-11_IGS-B1D1 from New York, United States). The loci of ITS and mtSSU consistent with IGS haplotype were observed in all $A$. areolatum isolates (D3, D18, D10, M1 and L29) from China (Table 3, Figure 4). 


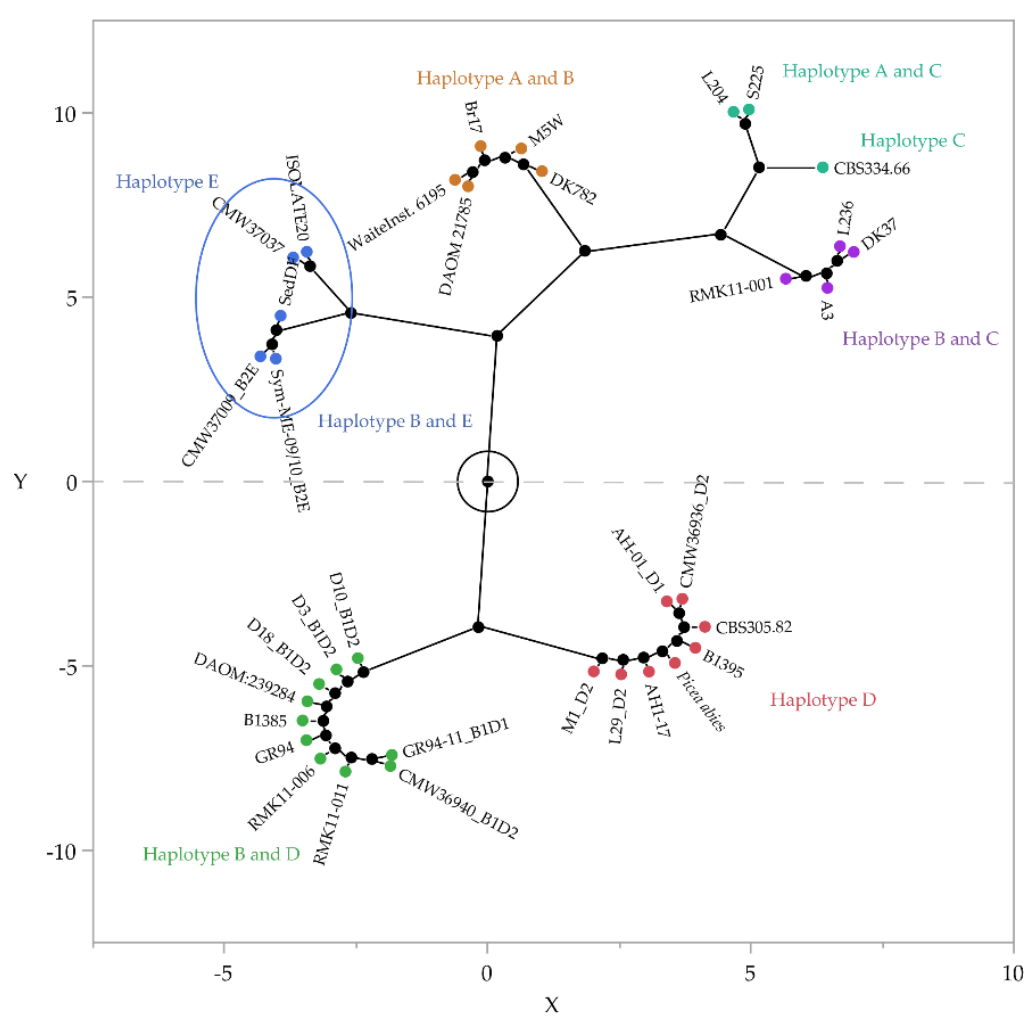

Figure 4. Hierarchical clustering analysis and constellation plot based on 35 isolates from the GenBank (Supplementary Table S1, unique sequence), and relatedness of haplotypes in the Amylostereum areolatum isolates from native and non-native Sirex specimens, from multiple locations in China. The plot arranges the A. areolatum isolates as endpoints, and each cluster join as a new point, whereas the lines represent membership in a cluster. The length of a line between cluster joins approximates the distance between the clusters that were joined, where $X$ - and Y-axes enable comparison of the relative distance between clusters; the longer the lines, the greater the distance between the clusters. The axis scaling, orientation of points, and angles of the lines on the constellation plot are arbitrary, with no assigned unit in SAS-JMP pro version 16.0.0.

\subsection{Co-Infestation of S. noctilio and S. nitobei in Pinus}

Among the Sirex species that emerged, S. noctilio and S. nitobei co-occurred in $41.4 \%$ of the 29 pine trees. For the 12 trees where co-occurrence within sections of trees could be determined, $74.7 \%(n=269)$ of $S$. nitobei emerged from sections of the trees where $S$. noctilio emerged, and $41.2 \%(n=466)$ of $S$. noctilio emerged from sections of the trees where S. nitobei emerged. S. nitobei mainly carried either IGS-D2 A. areolatum or A. chailletii. All S. noctilio females emerging from $P$. sylvestris var. mongolica tree carried A. areolatum IGS-B1D2 in different sites (DM, HG, JBT, YS) (Figure 5). Two female $S$. nitobei from the same sections of co-infested trees carried $A$. areolatum IGS-B1D2 in JBT (Table 4).

Table 4. Species and IGS strains of Amylostereum associated with Sirex noctilio and Sirex nitobei in the current study.

\begin{tabular}{ccccc}
\hline Sirex Host & Samples, $n$ & \multicolumn{2}{c}{ A. areolatum } & \multirow{2}{*}{ A. chailletii } \\
\cline { 3 - 4 } & & IGS-D2 & IGS-B1D2 & \\
\hline Sirex noctilio & 26 & - & 26 & - \\
Sirex nitobei & 44 & 18 & 2 & 24 \\
\hline
\end{tabular}




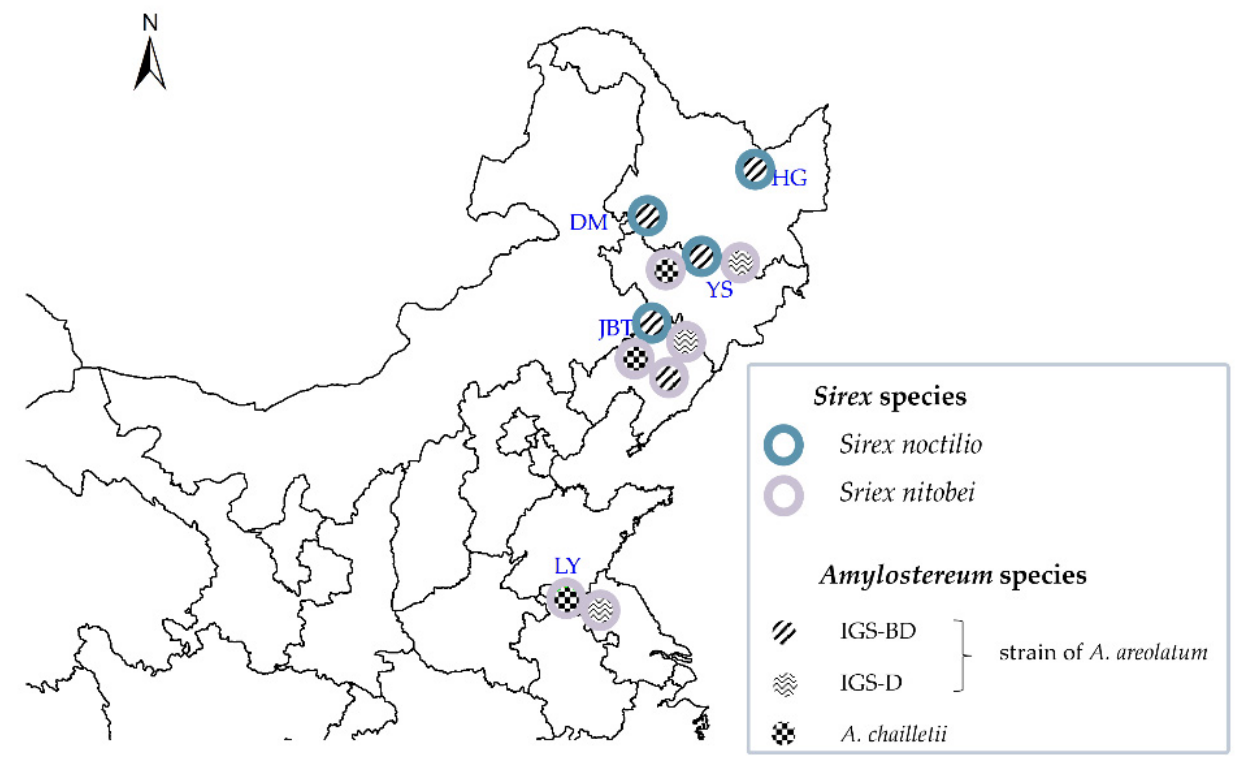

Figure 5. Distribution of the associations between Sirex species and Amylostereum species (strains) in China.

\section{Discussion}

S. noctilio was first found in the samples collected from Northeast China in 2013 [57]. Based on COI sequence, Sun et al. (2020) have reported the genetic diversity and structure of S. noctilio populations [58]. In some regions, S. noctilio and S. nitobei can infest the same trees [14]. To better understand the phylogenetic relationships within A. areolatum in China, we analyzed sequences from 27 strains $(59 \%)$ of A. areolatum isolates from sympatric distributions, plus 19 strains (41\%) of isolates from independent distributions. Isolates from the native and exotic countries were included to determine the patterns of geographical distribution and the origin of the introduced pest species in China.

\subsection{Multilocus Genotyping and IGS Heterogeneity of A. areolatum}

Multilocus sequencing of the $A$. areolatum isolates revealed three distinct $S$. noctilioassociated A. areolatum MLGs in Northeast China (Table 3), which have not been detected in S. noctilio-native countries. The MLGs A13, A14, and A15 exhibited sequence similarities with A8 (AH1-17) and A7 (B1385) reported by Castrillo et al. (2015), indicating that multiple $S$. noctilio species might have been introduced to China from Europe or North America (Figure 3, Table 3) [59]. These species originated probably from unrepresented source populations. Our results are consistent with the patterns of multiple invasions and the spread of S. noctilio across China [58]. Additional samples and heterogeneous genetic markers for assessing the population genetics of $A$. areolatum are required to determine whether these introductions occurred either through a direct route from Europe, or indirectly from North America, or a combination of both routes.

In addition to the observation of fragment size differences among the A. areolatum IGS rRNA sequences, we also paid attention to single nucleotide polymorphisms (SNPs). Two different-sized PCR products indicated the presence of a heterogenic sequence in the IGS of the nuclear rDNA locus in the A. areolatum isolates. This finding was confirmed by cloning and sequencing these fragments. We found only one genotype of $A$. areolatum in Northeast China was associated with $S$. noctilio, that is, the heterogeneous strain (BD), in contrast with the invasion of the southern hemisphere $(\mathrm{AB})$. The strain carried the $\mathrm{B}$ sequence, previously reported in Europe and the southern hemisphere [42], along with the D sequence. IGS-BD is widely distributed across five continents (Figure 6). The homogeneous strain (D) of $A$. areolatum associated with $S$. nitobei, which is found only in the northern hemisphere, was equivalent to an isolate obtained from S. nitobei in Japan (B1395) [59]. 


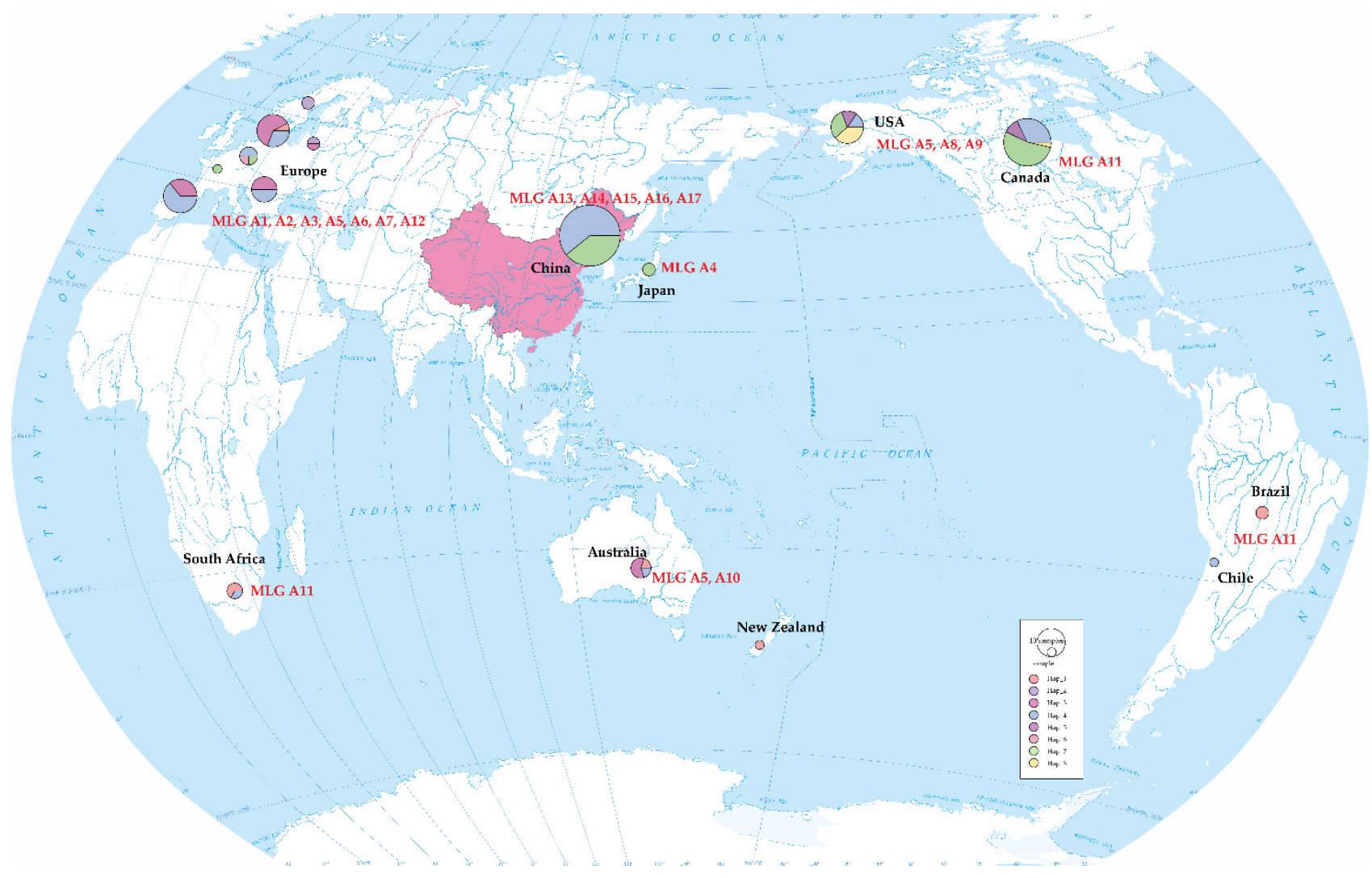

Figure 6. Global A. areolatum associated with woodwasp population haplotype distribution, based on the IGS region and MLGs.

\subsection{Sirex noctilio and S. nitobei-A. areolatum Association}

In this study, S. nitobei was found to carry A. areolatum-D, which were all collected from outside the known geographic repartition of $S$. noctilio (in Linyi), while a very small percentage of individuals carried A. areolatum-BD in sympatric distribution (S. noctilio and S. nitobei) and shared the same MLG A13 with S. noctilio. Moreover, S. noctilio and S. nitobei were sometimes observed as co-occurring on P. sylvestris var. mongolica, thereby providing the potential for horizontal transmission (S. noctilio share larval habitat with the native woodwasp when infesting the same trees) of fungal symbionts from sympatric $S$. noctilio. In addition, studies have shown the evolution of associations between these woodwasps and fungal symbionts allows plasticity [60-62]. Ann et al. (2018) found the spillover of A. areolatum from invasive S. noctilio to native Urocerus spp. [63], and the horizontal transmission of fungal strains from S. noctilio to S. nigricornis [45] in North America. In Spain, the newly introduced $U$. albicornis (well known to be associated with $A$. chailletii) was found to carry a European strain, A. areolatum [63]. Introduced fungi would definitely have vectored to new trees during oviposition by new woodwasp hosts; thus, horizontal transmission in associations would assist in the establishment and spread of the newly introduced wood-decay fungus.

According to Slippers et al. (2002) [42], the divergence of A. areolatum can be attributed to the obligate relationship of $A$. areolatum with its insect vectors, and to the predominance of asexual reproduction compared with other Amylostereum species. This study shows that the $A$. areolatum (MLG A15) isolates from China, collected over four years (from 2017 to 2020), represent a lineage of MLG A15 linked with the IGS-BD. There is no sequence variation in the nuclear IGS rRNA region. The results indicated that vegetative reproduction in its symbiosis with $S$. noctilio was the predominant or only form of reproduction in $A$. areolatum in northern China. Basidiocarps of $A$. areolatum have not been reported in these areas. In the ecology of Amylostereum spp., sexual reproduction could allow genetic recombination, leading to polymorphisms. However, asexual reproduction of $A$. areolatum 
and vertical transmission across generations by the woodwasp vector would result in the extensive spread of cloned fungus [64]. The sample size of the present study was insufficient for fully assessing the population genetics of the A. areolatum associated with S. noctilio in China. The close similarity of A14 and A15 from S. noctilio with A13 from S. noctilio and S. nitobei, and its associated IGS type in Northeast China, warrants further examination of $A$. areolatum genotypes associated with more native siricid species and additional European and North American samples.

\subsection{Focus for Further Research}

Symbiont fidelity is the main mechanism in the evolution and stability of mutualisms. Heterogenic sequences in the nuc-IGS-rDNA region of $A$. areolatum isolates make it possible to compare and characterize populations of these fungi that are associated with different wasp species. The occurrence and combination of these sequences provides insight into both the geographical distribution and evolutionary relationships of populations of fungus. Effective IPM strategies rely on determining the species and genetic variants present in a given population or region, especially where both native and invasive species are coinfesting. This study can fill in this knowledge gap by characterizing the population structure of $A$. areolatum in Northeast China. Our understanding of the $A$. areolatum population structure is limited, which further impedes the development and application of effective IPM approaches. Identification studies utilizing DNA sequence data on a large number of isolates from native areas, where diverse wasp species/populations co-exist, would be valuable. Such studies would make it possible to determine the extent of the levels of specificity between the symbiont and host.

Supplementary Materials: The following are available online at https:/ / www.mdpi.com/article/10 .3390/jof7121065/s1, Figure S1: Fluorescence profiles for two IGS genotypes of A. areolatum. The peaks on the far right are IGS fragments. (A) Peaks for D alone, (B) peaks for B and D.; Figure S2: Multiple alignment of IGS haplotype sequences (type B and D) of the Amylostereum areolatum isolates from Sirex nitobei and Sirex noctilio specimens conducted in MEGA 7 software. Table S1: The intergenic spacer sequences included in the identification of SNP markers for detection of specific haplotypes in Amylostereum areolatum isolated from Sirex woodwasps.

Author Contributions: Conceptualization, Y.L. and L.R.; methodology, M.W.; software, M.W.; formal analysis, M.W. and L.R.; investigation, M.W., N.F., C.G., L.W., L.R. and Y.L.; writing-original draft preparation, M.W.; writing-review and editing, L.R. and Y.L.; visualization, M.W.; supervision, L.R. and Y.L.; funding acquisition, L.R. and Y.L. All authors have read and agreed to the published version of the manuscript.

Funding: This research was funded by Chinese National Natural Science Foundation (31870642) and Beijing's Science and Technology Planning Project "Z201100008020001".

Institutional Review Board Statement: Not applicable.

Informed Consent Statement: Not applicable.

Data Availability Statement: Not applicable.

Acknowledgments: We thank Qinwang $\mathrm{Xu}$ and Zhengtong Wang for their assistance with sample collection, and the workers of the Forest Pest Control and Quarantine Station of Yushu City for their assistance with fieldwork.

Conflicts of Interest: The authors declare no conflict of interest.

\section{References}

1. Boidin, J. Hétérobasidiomycètes saprophytes et homobasidiomycètes résupinés. VII.-Essai sur le genre «Stereum sensu lato» (Troisième contribution). Bull. Mens. Soc. Linn. Lyon 1959, 28, 205-222. [CrossRef]

2. Pechmann, H.V. Untersuchungen uber die Rotstreifigkeit des Fichtenholzes. Summ. Forstw. Cbl. Beih. 1967, $27,112$.

3. Siepmann, R. Artdiagnose holzzerstörender Hymenomyceten an Hand vonReinkulturen. V. Nova Hedwig. 1979, 30, 69-78. [CrossRef]

4. Ginns, J.; Stalpers, J.A. Identification of Wood-Inhabiting Aphyllophorales in Pure Culture. Mycologia 1979, 71, 224. [CrossRef] 
5. Thomsen, I. Fruitbody characters and cultural characteristics useful for recognizing Amylostereum areolatum and A. chailletii. Mycotaxon 1998, 69, 419-428.

6. Morgan, F. Bionomics of Siricidae. Annu. Rev. Entomol. 1968, 13, 239-256. [CrossRef]

7. Cartwright, K. Notes on a fungus associated with Sirex cyaneus. Ann. Appl. Biol. 1929, 16, 182-187.

8. Coutts, M.P. The Mechanism of Pathogenicity of Sirex noctilio on Pinus radiata I. Effects of the Symbiotic Fungus Amylostereum sp. (Thelophoraceae). Aust. J. Biol. Sci. 1969, 22, 915-924. [CrossRef]

9. Coutts, M.P. The Mechanism of Pathogenicity of Sirex noctilio on Pinus radiata II. Effects of S. noctilio mucus. Aust. J. Biol. Sci. 1969, 22, 1153-1162. [CrossRef]

10. Hanson, H.S. Ecological Notes on the Sirex Wood Wasps and their Parasites. Bull. Entomol. Res. 2009, 30, 27-65. [CrossRef]

11. Talbot, P.H.B. The Sirex-Amylostereum-Pinus Association. Annu. Rev. Phytopathol. 1977, 15, 41-54. [CrossRef]

12. Stoddart, J.A.; Taylor, J.F. Genotypic diversity: Estimation and prediction in samples. Genetics 1988, 118, 705-711. [CrossRef]

13. Spradbery, J.P.; Kirk, A.A. Aspects of the ecology of siricid woodwasps (Hymenoptera: Siricidae) in Europe, North Africa and Turkey with special reference to the biological control of Sirex noctilio F. in Australia. Bull. Entomol. Res. 1978, 68, 341-359. [CrossRef]

14. Wang, M.; Bao, M.; Ao, T.G.; Ren, L.L.; Luo, Y.Q. Population distribution patterns and ecological niches of two Sirex species damaging Pinus sylvestris var. mongolica. Chin. J. Appl. Entomol. 2017, 54, 924-932. [CrossRef]

15. Hall, M.J. A Survey of Siricid Attack on Radiata Pine in Europe. Aust. For. 1968, 32, 155-162. [CrossRef]

16. Spradbery, J.P. A comparative study of the phytotoxic effects of siricid woodwasps on conifers. Ann. Appl. Biol. 1973, 75, 309-320. [CrossRef]

17. Lantschner, M.V.; Villacide, J.M.; Garnas, J.R.; Croft, P.; Carnegie, A.J.; Liebhold, A.M.; Corley, J.C. Temperature explains variable spread rates of the invasive woodwasp Sirex noctilio in the Southern Hemisphere. Biol. Invasions 2014, 16, 329-339. [CrossRef]

18. Spradbery, J.P. The oviposition biology of siricid woodwasps in Europe. Ecol. Entomol. 1977, 2, 225-230. [CrossRef]

19. Carnegie, A.J.; Bashford, R. Sirex Woodwasp in Australia: Current Management Strategies, Research and Emerging Issues. In The Sirex Woodwasp and Its Fungal Symbiont; Springer: Berlin/Heidelberg, Germany, 2012; pp. 175-201. [CrossRef]

20. Xu, Q. Bio-Ecological Characteristics, Monitoring and Silvicultural Control Technology of Invasive Alien Species Sirex noctilio in China. Ph.D. Thesis, Beijing Forestry University, Beijing, China, 2020. [CrossRef]

21. Gilbertson, R.L. Relationships between insects and wood-rotting Basidiomycetes. In Fungus-Insect Relationships, Perspectives in Ecology and Evolution; Columbia University Press: New York, NY, USA, 1984.

22. Vasiliauskas, R.; Stenlid, J.A.N.; Thomsen, I.M. Clonality and genetic variation in Amylostereum areolatum and A. chailletii from northern Europe. New Phytol. 1998, 139, 751-758. [CrossRef]

23. Thomsen, I.M. Amylostereum areolatum and Amylostereum chailletii: Symbiotic Fungi of Woodwasps (Sirex sp. and Urocerus sp.). Ph.D. Thesis, Danish Forest and Landscape Research Institute, Hoersholm, Denmark, 1996.

24. Slippers, B.; Coutinho, T.A.; Wingfield, B.D.; Wingfield, M.J. A review of the genus Amylostereum and its association with woodwasps. S. Arf. J. Sci. 2003, 99, 70-74. [CrossRef]

25. Margrete Thomsen, I.; Koch, J. Somatic compatibility in Amylostereum areolatum and A. chailletii as a consequence of symbiosis with siricid woodwasps. Mycol. Res. 1999, 103, 817-823. [CrossRef]

26. Slippers, B.; Wingfield, M.J.; Coutinho, T.A.; Wingfield, B.D. Population structure and possible origin of Amylostereum areolatum in South Africa. Plant Pathol. 2010, 50, 206-210. [CrossRef]

27. Wang, Y.; Lu, J.; Beattie, G.A.; Islam, M.R.; Om, N.; Dao, H.T.; Van Nguyen, L.; Zaka, S.M.; Guo, J.; Tian, M.Y. Phylogeography of Diaphorina citri (Hemiptera: Liviidae) and its primary endosymbiont, 'Candidatus Carsonella ruddii': An evolutionary approach to host-endosymbiont interaction. Pest Manag. Sci. 2018, 74, 2185-2194. [CrossRef]

28. Wang, M.; Wang, L.X.; Li, D.P.; Fu, N.N.; Li, C.C.; Luo, Y.Q.; Ren, L.L. Advances in the Study of Mutualism Relationship Between Amylostereum areolatum and Sirex noctilio. J. Temp. For. Res. 2020, 3, 1-11.

29. Fitza, K.N.E.; Tabata, M.; Kanzaki, N.; Kimura, K.; Garnas, J.; Slippers, B. Host specificity and diversity of Amylostereum associated with Japanese siricids. Fungal. Ecol. 2016, 24, 76-81. [CrossRef]

30. Bergeron, M.J.; Leal, I.; Foord, B.; Ross, G.; Davis, C.; Slippers, B.; de Groot, P.; Hamelin, R.C. Putative origin of clonal lineages of Amylostereum areolatum, the fungal symbiont associated with Sirex noctilio, retrieved from Pinus sylvestris, in eastern Canada. Fungal. Biol. 2011, 115, 750-758. [CrossRef] [PubMed]

31. Schiff, N.M.; Goulet, H.; Smith, D.R.; Boudreault, C.; Scheffler, B.E. Siricidae (Hymenoptera: Symphyta: Siricoidea) of the Western Hemisphere. Can. J. Arthropod Identif. 2012, 21, 1-305. [CrossRef]

32. Gardes, M.; Bruns, T.D. ITS primers with enhanced specificity for basidiomycetes-Application to the identification of mycorrhizae and rusts. Mol. Ecol. 1993, 2, 113-118. [CrossRef]

33. Morehouse, E.A.; James, T.Y.; Ganley, A.R.; Vilgalys, R.; Berger, L.; Murphy, P.J.; Longcore, J.E. Multilocus sequence typing suggests the chytrid pathogen of amphibians is a recently emerged clone. Mol. Ecol. 2003, 12, 395-403. [CrossRef]

34. Liu, Y.J.; Whelen, S.; Hall, B.D. Phylogenetic relationships among ascomycetes: Evidence from an RNA polymerse II subunit. Mol. Biol. Evol. 1999, 16, 1799-1808. [CrossRef]

35. White, T.; Bruns, T.; Lee, S.; Taylor, F.; White, T.; Lee, S.H.; Taylor, L.; Shawetaylor, J. Amplification and direct sequencing of fungal ribosomal RNA genes for phylogenetics. In PCR Protocols: A Guide to Methods and Applications; Innis, M.A., Gelfand, D.H., Sninsky, J.J., White, T.J., Eds.; Academic Press: San Diego, CA, USA, 1990; pp. 315-322. [CrossRef] 
36. Thompson, J.D.; Higgins, D.G.; Gibson, T.J. CLUSTAL W: Improving the sensitivity of progressive multiple sequence alignment through sequence weighting, position-specific gap penalties and weight matrix choice. Nucleic Acids Res. 1994, 22, 4673-4680. [CrossRef] [PubMed]

37. Hall, T.A. BioEdit: A User-Friendly Biological Sequence Alignment Editor and Analysis Program for Windows 95/98/NT. Nuclc Acids Symp. Ser. 1999, 41, 95-98. [CrossRef]

38. Xia, X. DAMBE6: New Tools for Microbial Genomics, Phylogenetics, and Molecular Evolution. J. Hered. 2017, 108, 431-437. [CrossRef] [PubMed]

39. Xia, X.; Lemey, P. The Phylogenetic Handbook: Assessing Substitution Saturation with DAMBE; Cambridge University Press: Cambridge, UK, 2009.

40. Xia, X.; Xie, Z.; Salemi, M.; Chen, L.; Wang, Y. An index of substitution saturation and its application. Mol. Phylogenet. Evol. 2003, 26, s1055-s7903. [CrossRef]

41. Hsiau, T.W. The Taxonomy and Phylogeny of the Mycangial Fungi from Dendroctonus brevicomis and D. frontalis (Coleoptera: Scolytidae). Ph.D. Thesis, Iowa State University, Ames, IA, USA, 1996.

42. Slippers, B.; Wingfield, B.D.; Coutinho, T.A.; Wingfield, M.J. DNA sequence and RFLP data reflect geographical spread and relationships of Amylostereum areolatum and its insect vectors. Mol. Ecol. 2002, 11, 1845-1854. [CrossRef] [PubMed]

43. Stalpers, J. Identification of Wood-Inhabiting Aphyllophorales in Pure Culture Studies in Mycology 16; CBS: Baarn, The Netherlands; Centraalbureau voor Schimmelcultures: Utrecht, The Netherlands, 1978; p. 224.

44. Siepmann, R. Artdiagnose einiger holzzerstörender Hymenomyceten an Hand von Reinkulturen. IV. Nova Hedwig. Allem. Da. 1971, 21, 843-875.

45. Hajek, A.E.; Nielsen, C.; Kepler, R.M.; Long, S.J.; Castrillo, L. Fidelity among Sirex woodwasps and their fungal symbionts. Microb. Ecol. 2013, 65, 735-762. [CrossRef] [PubMed]

46. Kimura, M. Estimation of evolutionary distances between homologous nucleotide sequences. Proc. Natl. Acad. Sci. USA 1981, 78, 454-458. [CrossRef]

47. Felsenstein, J. Evolutionary trees from DNA sequences: A maximum likelihood approach. J. Mol. Evol. 1981, 17, 368-376. [CrossRef]

48. Zhang, D.; Gao, F.; Jakovlic, I.; Zou, H.; Zhang, J.; Li, W.X.; Wang, G.T. PhyloSuite: An integrated and scalable desktop platform for streamlined molecular sequence data management and evolutionary phylogenetics studies. Mol. Ecol. Resour. 2020, 20, 348-355. [CrossRef] [PubMed]

49. Nguyen, L.T.; Schmidt, H.A.; von Haeseler, A.; Minh, B.Q. IQ-TREE: A fast and effective stochastic algorithm for estimating maximum-likelihood phylogenies. Mol. Biol. Evol. 2015, 32, 268-274. [CrossRef] [PubMed]

50. Minh, B.Q.; Nguyen, M.A.; von Haeseler, A. Ultrafast approximation for phylogenetic bootstrap. Mol. Biol. Evol. 2013, 30, 1188-1195. [CrossRef] [PubMed]

51. Guindon, S.; Dufayard, J.F.; Lefort, V.; Anisimova, M.; Hordijk, W.; Gascuel, O. New algorithms and methods to estimate maximum-likelihood phylogenies: Assessing the performance of PhyML 3.0. Syst. Biol. 2010, 59, 307-321. [CrossRef] [PubMed]

52. Leigh, J.W.; Bryant, D. Popart: Full-feature software for haplotype network construction. Methods Ecol. Evol. 2015, 6, 1110-1116. [CrossRef]

53. Olatinwo, R.O.; Schowalter, T.D.; Doucet, D.; Bowman, S.; Johnson, W.C.; Allison, J.D.; Morisette, J. Intergenic Spacer Single Nucleotide Polymorphisms for Genotyping Amylostereum areolatum (Russulales: Amylostereacea) Symbionts of Native and Non-native Sirex Species. Ann. Entomol. Soc. Am. 2020, 113, 280-287. [CrossRef]

54. Nielsen, C.; Williams, D.W.; Hajek, A.E. Putative source of the invasive Sirex noctilio fungal symbiont, Amylostereum areolatum, in the eastern United States and its association with native siricid woodwasps. Mycol. Res. 2009, 113, 1242-1253. [CrossRef] [PubMed]

55. Wooding, A.L.; Wingfield, M.J.; Hurley, B.P.; Garnas, J.R.; de Groot, P.; Slippers, B. Lack of fidelity revealed in an insect-fungal mutualism after invasion. Biol. Lett. 2013, 9, 20130342. [CrossRef] [PubMed]

56. Olatinwo, R.; Allison, J.; Meeker, J.; Johnson, W.; Streett, D.; Aime, M.C.; Carlton, C. Detection and identification of Amylostereum areolatum (Russulales: Amylostereaceae) in the mycangia of Sirex nigricornis (Hymenoptera: Siricidae) in central Louisiana. Environ. Entomol. 2013, 42, 1246-1256. [CrossRef] [PubMed]

57. Li, D.P.; Shi, J.; Luo, Y.Q. Mutualism between the Eurasian woodwasp, Sirex noctilio (Hymenoptera: Siricidae) and its fungal symbiont Amylostereum areolatum (Russulales: Amylostereaceae). Acta Entomol. Sin. 2015, 58, 1019-1029. [CrossRef]

58. Sun, X.; Tao, J.; Roques, A.; Luo, Y. Invasion History of Sirex noctilio Based on COI Sequence: The First Six Years in China. Insects 2020, 11, 111. [CrossRef]

59. Castrillo, L.A.; Hajek, A.E.; Pajares, J.A.; Thomsen, I.M.; Csoka, G.; Kenaley, S.C.; Kepler, R.M.; Zamora, P.; Angeli, S. Multilocus genotyping of Amylostereum spp. associated with Sirex noctilio and other woodwasps from Europe reveal clonal lineage introduced to the US. Fungal. Biol. 2015, 119, 595-604. [CrossRef] [PubMed]

60. Aanen, D.K.; Eggleton, P.; Rouland-Lefevre, C.; Guldberg-Frøslev, T.; Rosendahl, S.; Boomsma, J.J. The evolution of fungusgrowing termites and their mutualistic fungal symbionts. Proc. Natl. Acad. Sci. USA 2002, 99, 14887-14892. [CrossRef] [PubMed] 
61. Harrington, T.C. 11. Ecology and evolution of mycophagous bark beetles and their fungal partners. Insect Fungal Associations. Available online: https:/ / www.semanticscholar.org/paper/Ecology-and-evolution-of-mycophagous-bark-beetles-HarringtonVega/f3ce0b8255adbe467a6e1cbe4ac5c66130d1cd21 (accessed on 9 December 2021).

62. Harrington, T.C.; Aghayeva, D.N.; Fraedrich, S.W. New combinations in Raffaelea, Ambrosiella, and Hyalorhinocladiella, and four new species from the redbay ambrosia beetle, Xyleborus glabratus. Mycotaxon 2010, 111, 337-361. [CrossRef]

63. Hajek, A.E.; Harris, D.C.; Bittner, T.D. Symbiont Spillover from Invasive to Native Woodwasps. Microb. Ecol. 2018, 75, 7-9. [CrossRef] [PubMed]

64. Slippers, B.; Hurley, B.P.; Wingfield, M.J. Sirex woodwasp: A model for evolving management paradigms of invasive forest pests. Annu. Rev. Entomol. 2015, 60, 601-619. [CrossRef] 